\title{
The rise of the Mediterranean woody crops in Southern Spain
}

\author{
Garrido Almonacid, A. \& Sánchez Martínez, J. D.
}

\begin{abstract}
The area occupied by woody crops in Spain has undergone an enormous increase in size and, more importantly, a profound green revolution that generates enormous harvest volumes that nourish the important national agro-export sector, where products such as olive oil, wine and almonds reach a notable significance. The processes of intensification follow a common pattern, which involves the occupation of the flattest and most fertile soils by firms with an ownership structure favourable for investment; the use of new varieties; and the design of denser planting patterns in which irrigation is an indispensable element and mechanization ubiquitous.

The management of digitized spatial information has allowed us to map the evolution of the land uses of the olive grove, the vineyard and the almond orchard in each of the provinces where the regional specialization in these crops is greatest. This has allowed us to learn the key spatial/temporal aspects of these processes of change that are far from complete and that have led to a profound modification of agricultural landscapes, such that fragmentation and polyculture are giving way to geometry, compactness and the concentration of monoculture.
\end{abstract}

Keywords - almond, changes in land uses, olive grove, productivism, vineyard

\section{INTRODUCTION}

The major trends in the evolution of land use in Spain in recent decades are, in general terms, the reduction in the area under cultivation, the increase of irrigation and the expansion of woodlands. These are all manifestations of the same process that involves either abandoning agricultural activities or extending them from the places that turn out to be less productive in order to concentrate efforts on those areas that facilitate productivism. In this context, the area occupied by

Received: 12/12/2017, Accepted: 29/01/2018; Published: $30 / 3 / 2018$

Garrido Almonacid, A. \& Sánchez Martínez, J. D., University of Jaén, Spain. fruit trees, olive trees and vineyards has grown. Taken together, these three uses generate $25 \%$ of the value of the country's agricultural production and a third of its agri-food exports (Hueso Martín \& Cuevas González, 2014). The type of fruit produced is quite varied (citrus, stone and pip fruit, nuts, Mediterranean fruit trees, tropical and subtropical fruits), in line with the breadth of agrienvironmental conditions in the national territory. The economic and social importance of these crops is based on a permanent intensification effort, which includes, in addition to other aspects, the improvement of the genetic material or the universalization of irrigation. And among the reasons that have facilitated its expansion are the advantages derived from the accession to the European Common Market (1986) and the dietary changes that have been promoted due to increased awareness about the importance to the health of the consumption of fruits and vegetables and the virtues of the Mediterranean diet (Barjol, 2014).

In the present work, we focus on the evolution experienced by three of the most emblematic Mediterranean woody crops (olive groves, vineyards and almond trees) in areas of the interior of southern Spain, lands relegated to playing a peripheral and dependent role during the modernization process of the Spanish economy since the mid-twentieth century, which confirmed their role as suppliers of agricultural products and, later, tourism services, something that has only been strengthened during the subsequent globalization of the economy (Delgado Cabeza, 2002). Domestically, the impact of this role has resulted in a major territorial adjustment, so that urban centres and coastal areas grew at the expense of rural areas, which became less and less populated and dynamic, especially in places where it was not possible for intensive agriculture to spread. In particular, it proved disastrous for mountain areas (Araque Jiménez, 2009).

In the rural areas with the greatest agricultural presence, there has also been a profound reorientation of production, so that horticultural crops have taken on an unprecedented role. The 
productivism of irrigated olive groves in the province of Jaén, vineyards in trellis in Ciudad Real, or the industrialized fruit and vegetable operations on the Almeria coastline, contrast sharply with the landscape that existed until a few decades ago when the predominant agriculture was territorially based, which was reflected in the pre-eminence of rain-fed lands for the production of cereals, legumes and tubers (Cano Orellana, 2009).

\section{CONCEPTUAL AND} METHODOLOGICAL FRAMEWORK

In the last two decades it has been postulated that Western European agriculture is in transition towards multifunctionality (the rural development paradigm), thus overcoming the model of agrarian modernization prevalent until the 1980s (Evans, 2001; Van der Ploeg and Roep, 2003; OECD, 2006). This process is, in part, in agreement with the reallocation of functions that rural areas of developed countries are experiencing as a result of neoliberal globalization, which has succeeded in locating the massive production of low cost crops (commodities) in impoverished areas, where it is possible to monopolize resources and added value. It would thus follow that the more advanced European countries find a favourable setting for the testing of post-Fordist strategies on their own lands (Binimelis and Ordinas, 2012). In the present case, the worldwide expansion of typical (though not exclusive) Mediterranean crops such as vineyards, olive groves and almond trees are obvious, with the number of countries where they are present increasing, but this has not been incompatible with its strengthening and intensification in traditional production areas (Moreno-Pérez, 2013), which is where they are still mostly located.

Thus, to the extent that Europe delocalized the production of cereals, protein crops or industrial plants, the easier it was to specialize in some of its better productive options. This is more than evident in the case of Spain, where one can observe how the monoculture zones of olives, almonds and vineyards are being progressively strengthened in the search for better productive conditions while trying out different planting configurations that significantly facilitate the mechanization of the labour. This implies, conversely, the coexistence of two contrasting, if not radically different, business models. On the one hand, the modern agrarian business model is based on strong capitalization, with the aim of increasing the harvest and reducing the costs of production in order to ensure a healthy bottom line able to amortize the investments quickly. On the other hand, there is the family farm, associated with a smallholder ownership structure and little or no profitability, whose continuation would not be possible without aid from the European Union, and often includes the supplementation from income obtained in other sectors of activity and even the existence of an emotional attachment to the land that takes precedence over strictly economic criteria. Of course, between both extreme cases can be found multiple intermediate situations.

Our work has been based on the analysis of digitized information that allows us to construct the spatial-temporal dynamics of agricultural land uses. From the analysis of statistical information and the overlapping of territorial variables spatially referenced to the agricultural parcels, we have selected the three geographic areas in which the Mediterranean woody crops have a greater surface area importance in order to illustrate the indicated changes, thereby looking for the stages and clues that allow us to understand their rise, understood not only in terms of the expansion of the area planted, but also with regard to the migration of these crops towards those lands with better agronomic capacities and physical dimensions.

The interviews with international experts in each one of these crops and the consultation of different official documents, for their part, have allowed us to introduce qualitative aspects that help us to understand that, ultimately, the processes described result from the permanent tension between local and global factors.

\section{RESULTS}

Being cultivated predominantly in the Mediterranean and having spread over a number of countries on all continents, as can be seen in the maps presented in Figure 1, it is clear that olive and almond trees are located in a latitudinal range more limited that the vineyard, whose plasticity has taken it to countries like Canada or Russia, where the other two crops do not have appropriate ecological niches for their expansion. 

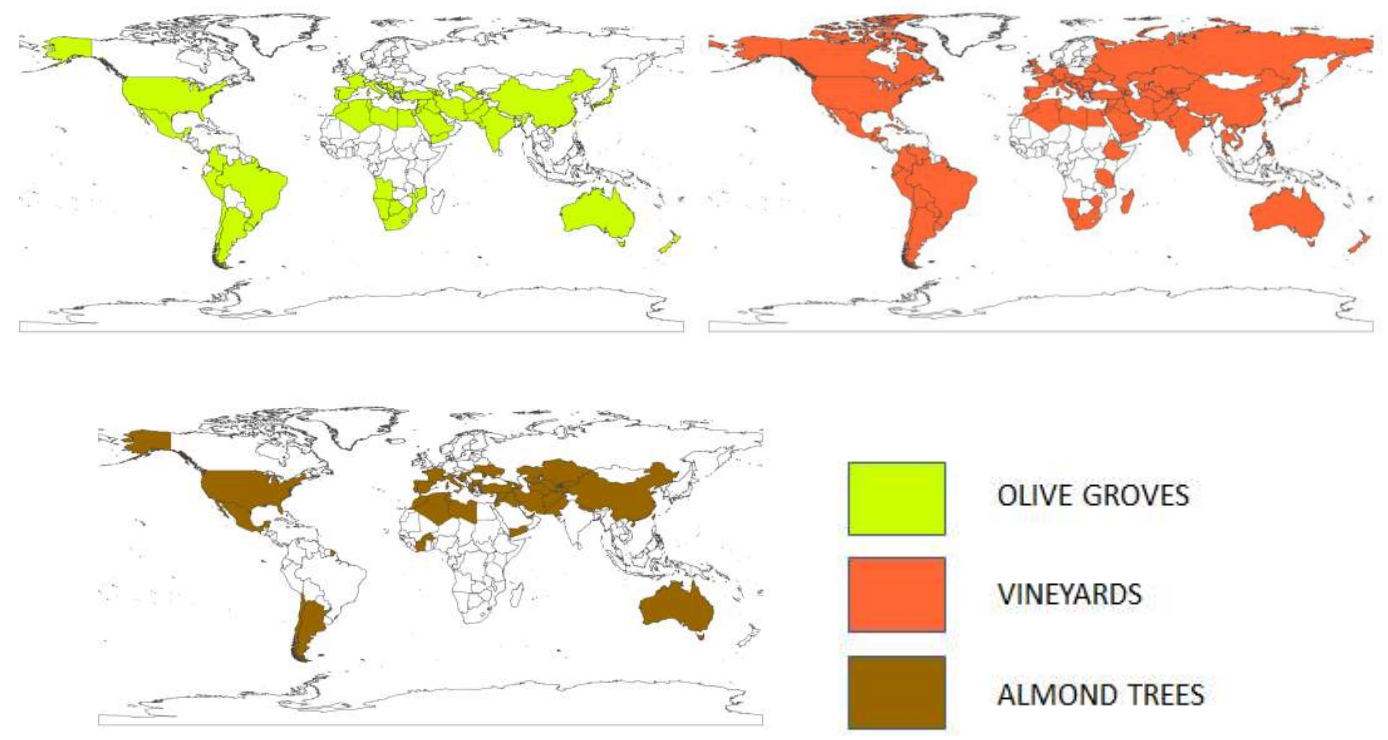

OLIVE GROVES

VINEYARDS

ALMOND TREES

Figure 1. Countries in which olive groves, almond orchards and vineyards are found (2014)

Source: $\underline{\text { http://www.fao.org/faostat/es/\#data }}$

Contemplated on a planetary scale, the sum of the area occupied by these three crops has grown spectacularly in the last half century, from 12.6 to 19.1 Mha (see Figure 2). However, the behaviour has not been homogeneous, because while in the case of the vineyard the area has been reduced by $25 \%$, the olive grove has multiplied its area by 3.9 times and the almond tree by 2.4 times during that same period. This indicates that the growth in the harvests from vineyards has come about through intensification, while a combination of surface area expansion and productivism is responsible for the extraordinary growth in the global harvests of olives and almonds.

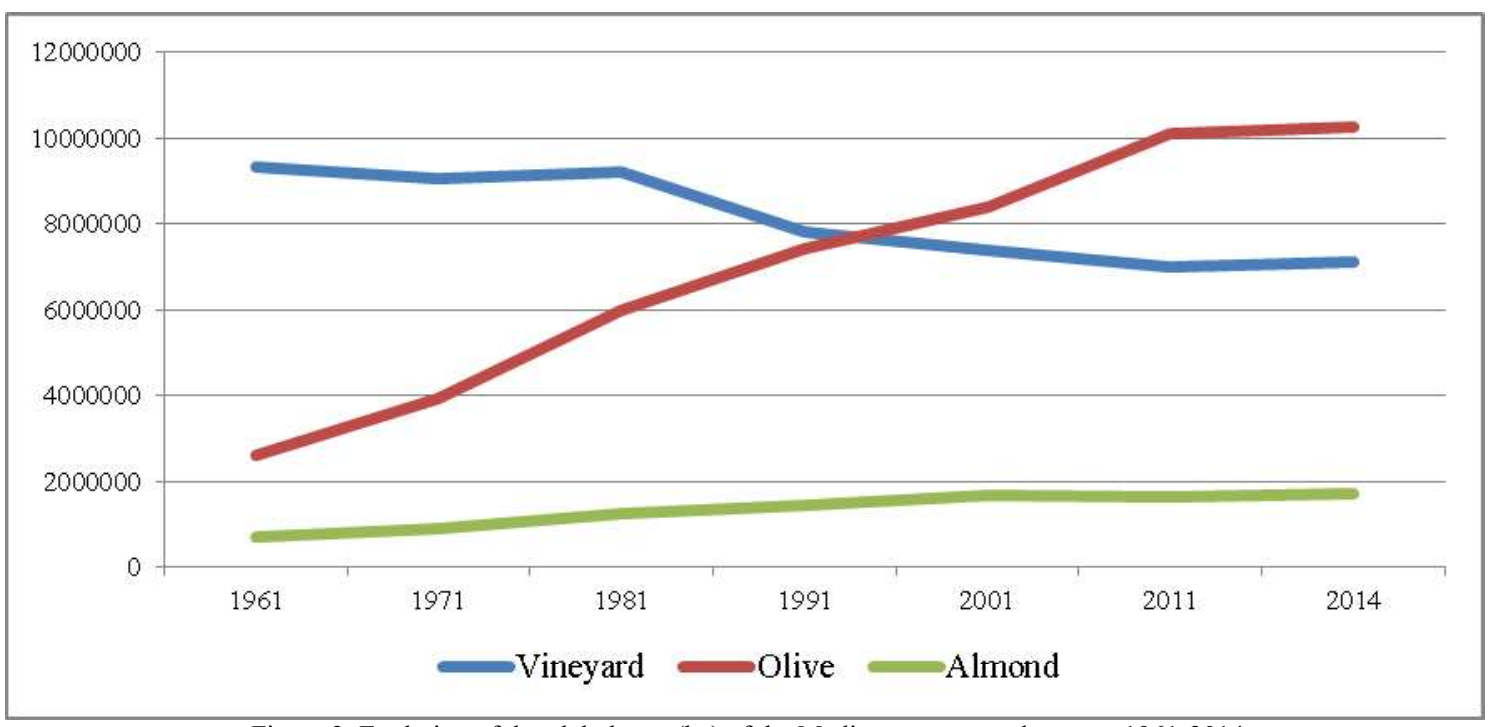

Figure 2. Evolution of the global area (ha) of the Mediterranean woody crops, 1961-2014

Source: http://www.fao.org/faostat/es/\#data

Among all the countries that have some area dedicated to these crops, Spain is in first place in all three and dominates the landscape in almonds (more than 30\% worldwide) and olives (almost
25\%) (Figure 3). This does not necessarily imply that it has the best productive ratios because, in contrast to those countries that concentrate their production in small locations where intensive 
agriculture is practiced, in Spain these crops occupy a wide variety of terrain and in all three a structure of smallholder ownership is clearly dominant. One example is the super-intensive cultivation of the almond tree in California, thanks to which the United States is the world's largest producer, compared to the marginal locations that predominate in the semi-arid mountainous regions surrounding the Spanish Mediterranean coast, where the yields are much smaller and less stable.

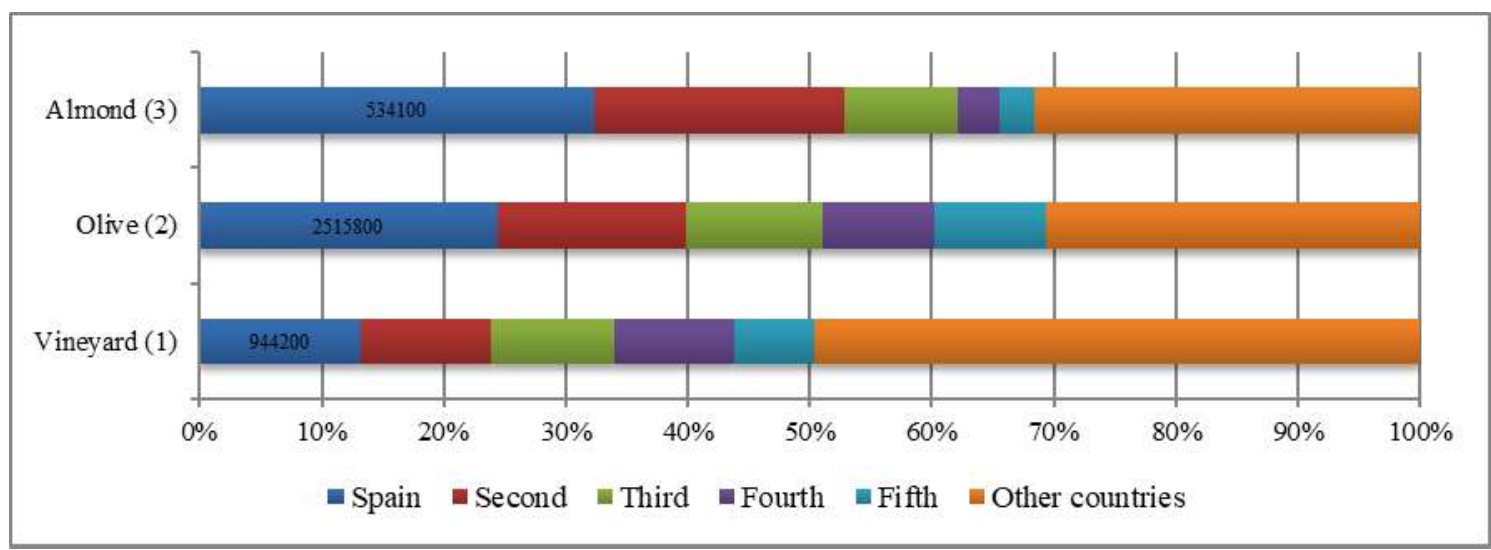

Figure 3. Surface area importance of the Mediterranean woody crops in Spain compared to other producers $(*)$

(*) The number in the interior of the blue bar shows the surface area (ha).

(1) Second to fifth: France, China, Italy and Turkey; (2) Second to fifth: Italy, Tunisia, Turkey and Greece; (3) Second to fifth: USA, Morocco, Italy and Libya.

Source: http://www.fao.org/faostat/es/\#data

We have collected in Figure 4 the evolution of the surface area in the last thirty years in Spain and observe the same global trends mentioned above. In fact, they are very influenced by what has happened in this country regarding the case of the olive and the vineyard. On the other hand, Table 1 shows the importance that irrigation has acquired for crops that were traditionally rain-fed.

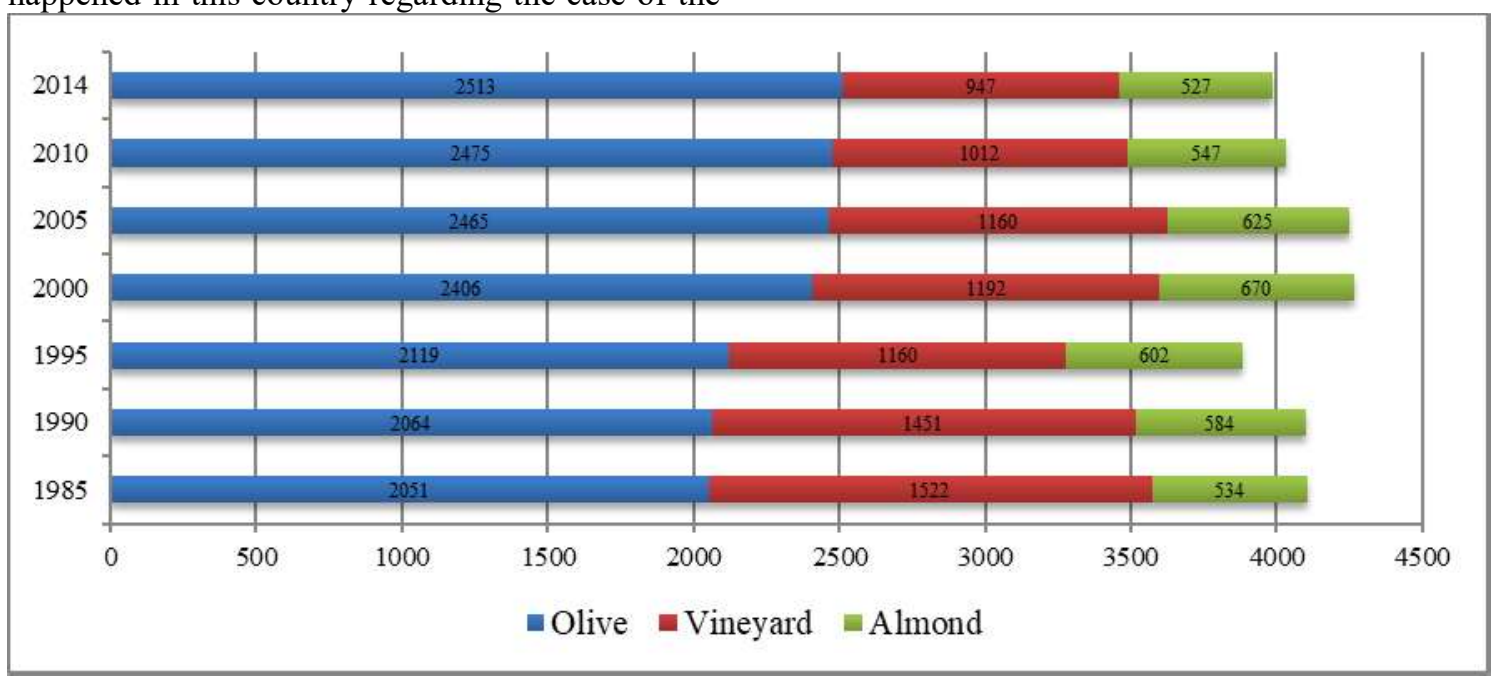

Figure 4. Evolution in the surface area dedicated in Spain to olive groves, vineyards and almonds trees orchards, 1985-2014 $\left(^{*}\right)$

$\left(^{*}\right)$ The number in the interior of the bar shows the surface area (thousands of ha). Source: http://www.mapama.gob.es/es/estadistica/temas/publicaciones/anuario-de-estadistica/ 
TẠP CHÍ PHÁT TRIỂN KHOA HỌC \& CÔNG NGHẸ:

CHUYÊN SAN KHOA HỌC XÃ HộI VÀ NHÂN VĂN, TẬP 1, SỐ 1, 2018

Table 1

Surface area according to cultivation system (ha) of the Mediterranean woody crops in Spain, 2014

\begin{tabular}{lllll}
\hline & Rain-fed (a) & Irrigated (b) & Total (c) & \% b/c \\
\hline Olive grove & $1,902,392$ & 613,415 & $2,515,807$ & 24.38 \\
Vineyard & 725,074 & 222,544 & 947,618 & 23.48 \\
Almond & 480,259 & 45,770 & 527,029 & 8.68 \\
Total & $3,107,725$ & 881,729 & $3,990,454$ & 22.10 \\
\hline \multicolumn{4}{r}{ Source: http://www.mapama.gob.es/es/estadistica/temas/publicaciones/anuario-de-estadistica/ }
\end{tabular}

The case of the almond tree, however, diverges from the uninterrupted trend lines of the rise of the olive tree and the decline of the vineyard. In this regard, a maximum was reached at the end of the 20 th century, and thereafter the surface area began to shrink. But this trend has once again changed in recent years when there has been talk of an almond boom, stimulated greatly by the sudden rise in prices of this nut as a result of the prolonged drought period experienced in California. Despite the fact that the dry period has ended and prices have now returned to normal compared to other years, it is estimated that the new plantations that are being developed in different parts of Espala (Aragon, Andalusia and Castilla-La Mancha fundamentally) are going to allow the national almond production to double over a period of seven years. ${ }^{1}$ Of course, the only way to compete adequately with US farms is to develop productivist plantations on farm holdings larger than the traditional ones and that occupy flatter and more fertile soils.

The example of the province of Granada can serve to illustrate this point. At the moment, the almond crop is mostly rain-fed and shows significant deficiencies in production, so that it can be classified as marginal both in terms of economic results and in relation to the physical capacity of the soils that the permanent crops occupy. Some characteristics of this dominant model are small-sized farms, the atomization of the property, the aging of the farm managers and the difficulty in ensuring the generational succession. In fact, recent research has shown that up to a third of current farmers are considering abandoning their farms in the Andalusian region due to a lack of profitability (Aznar-Sánchez, Belmonte-Ureña \& Velasco-Muñoz, 2016). This situation is aggravated in the mountainous locations, which are predominant in the province that we have chosen as a model of the processes of

\footnotetext{
${ }^{1}$ Story appearing in the newspaper La Verdad de Murcia (September 5, 2016).

http://www.laverdad.es/alicante/201609/05/menosalmendra-espanola-barata-20160905161629.html
}

change that we are describing, whose paradigm may be the coastal mountains of Lújar and Contraviesa or the pre-littoral area of the Sierra Nevada, where high altitude slopes are cultivated. In these cases, the only options that have been explored to improve the situation are variety renewal and organic production, since an average production of $566 \mathrm{~kg}$ of almonds with shell per hectare is obtained.

At the same time, although still with limited effect, plantations from the provincial interior (Hoyas de Guadix and Baza) located on flat lands and with a different climate are beginning to take on a more prominent role in comparison with the traditional concentration in the coastal area (Figures 5 and 6). In these cases, access to irrigation and the possibility of mechanized labour have been combined with the introduction of new varieties adapted to overcoming adverse weather conditions, in particular the risk of frost, something that can be achieved with late flowering varieties. New denser planting configurations and more efficient pruning methods have also been developed (Lovera, Serrano and Arquero, 2016). All these innovations are coming to farms thanks to the transfer of knowledge generated in public research centres, which base their recommendations on the imitation of the intensive farming methods from Australia and California, in which under optimal conditions they can produce up to $2,500 \mathrm{~kg}$ of shelled almond per hectare, still very far from the production levels that farms in Andalusia are beginning to obtain. In addition, in spite of everything, the available water resources are below the optimum. However, with localized deficit irrigation applied at ideal times for the development of the plant and the fruit, these farms are expected to obtain average yields of more than $1,000 \mathrm{~kg}$ of nuts per hectare, that is to say, more than twice what is obtained on traditional farms. 


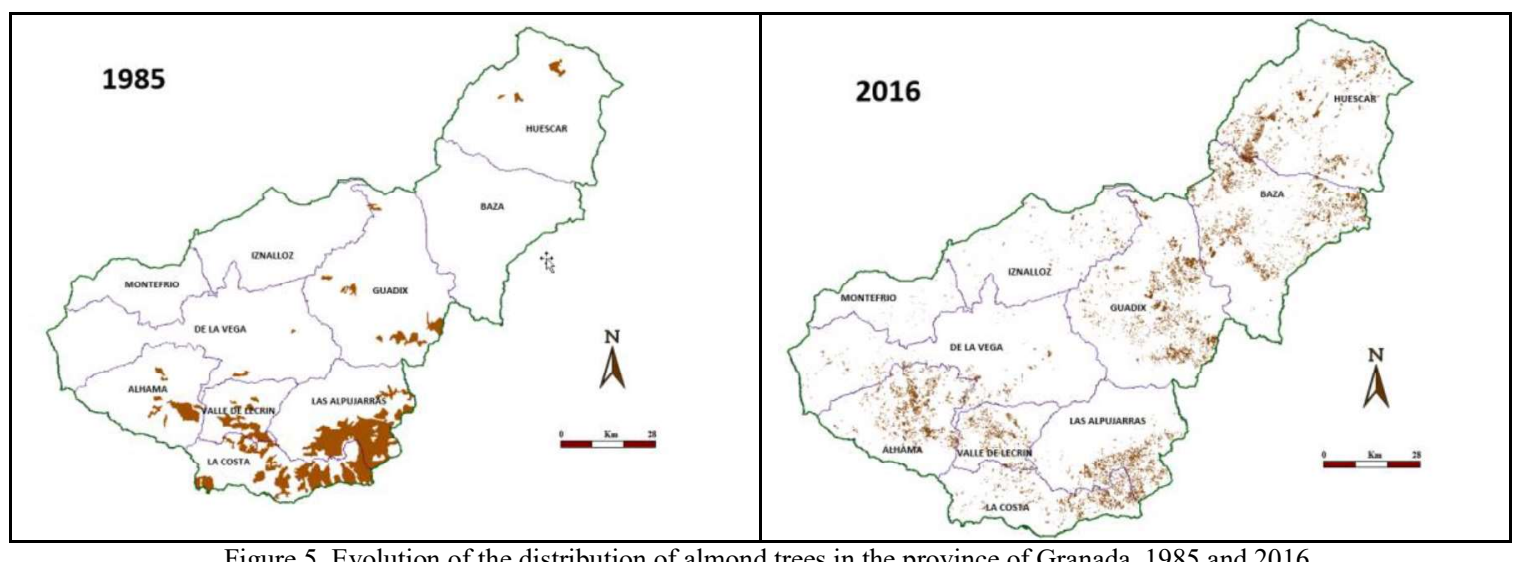

Figure 5. Evolution of the distribution of almond trees in the province of Granada, 1985 and 2016

Source: Environmental Information Catalogue of Andalusia 1985 and SIGPAC 2016.

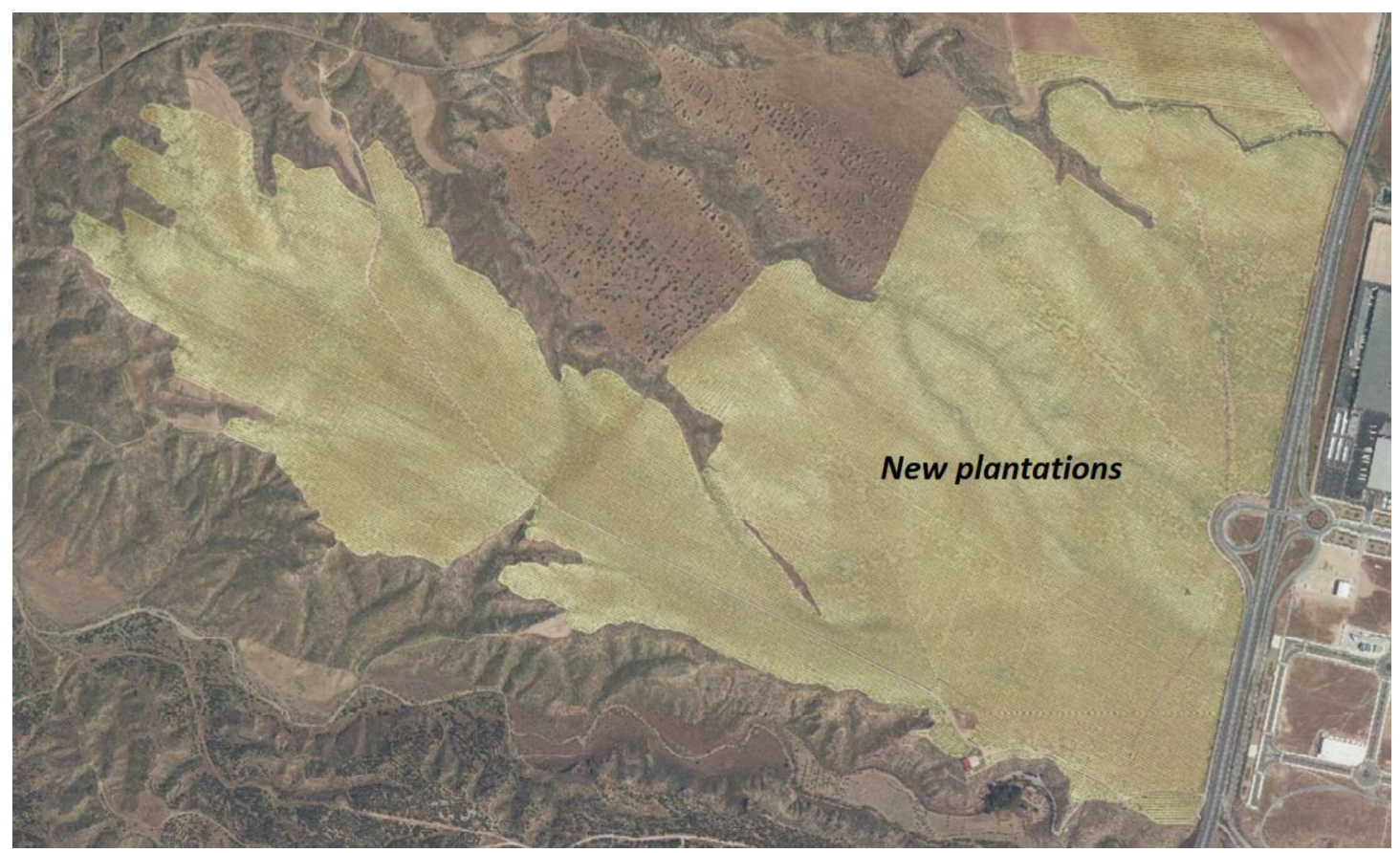

Figure 6. New plantations of almond trees in Guadix (Granada), 2016

Source: National Aerial Ortophoto Program (PNOA) - 2016

In the case of the vineyard, although the final result is a reduction of the total area, the effort has concentrated on making farms more profitable through a restructuring program that has meant the removal of extensive vineyards with traditional varieties in favour of plantations in trellis. Although this process is similar to the one we have explained for the almond tree, it took place earlier and is, in fact, the mirror in which other woody crops have been looked at later. The vineyard lands were transformed earlier, more rapidly and more intensely than the rest of the Mediterranean woody crops due to the enormous competitiveness existing in the international and globalized wine market, into which new countries have entered such as Australia, New Zealand, South Africa, Chile, Argentina, the United States or China, with an unusual strength thanks to their commercial aggressiveness and lower production costs. The traditional European producers, for their part, have been wagering on differentiation as a way to maintain their position. In this regard, in Spain a total of 91 Protected Designations of Origin and 41 Protected Geographical Indications have been 
TẠP CHÍ PHÁT TRIỂN KHOA HỌC \& CÔNG NGHẸ:

CHUYÊN SAN KHOA HỌC XÃ HộI VÀ NHÂN VĂN, TẬP 1, SỐ 1, 2018

recognized. ${ }^{2}$ A further step in the search for differentiated quality is the development of the socalled estate wines, oriented towards singularisation (Ruiz Pulpón, 2013a).

But the quest for quality has also been pursued with the modernization of the cultivation process by following the formulas already mentioned, such as varietal renewal, the densification of plantations to facilitate the mechanization of the labour and the introduction of irrigation. In this regard, the aid received through the vineyard reconversion and restructuring programs, financed by European funds, has proved decisive, the most obvious effect of which has been the formation of large continuous patches supported by a more concentrated and localized ownership structure on flatter and more fertile lands (Lasanta, Inarejos, Arnáez, Pascual Bellido \& Ruiz-Flaño, 2016).

The innovations, obviously, are not limited in this case to the agricultural labour, but are complemented decisively in the processes of winemaking and its subsequent treatment in the wineries. The subsequent recognition of the wines most appreciated in competitions, prizes and specialized publications, along with the promotion of wine and vineyard culture, and the landscapes and heritage associated with it, are decisive in order to satisfy a clientele that is more demanding and knowledgeable about the characteristics of this food product (Cañizares Ruiz \& Ruiz Pulpón, 2014, Escalona Orcao, Loscertales Palomar \& Climent López, 2013). However, strategies based on innovation and differentiation or singularisation still coexist with others, more oriented towards obtaining large volumes of undifferentiated crops (Esteban Rodríguez \& Climent López, 2016). A good example of the impact of the new plantations was the 2013 campaign, when favourable weather conditions allowed Spain to produce $51 \mathrm{Mhl}$ (five times its annual domestic consumption) with a considerably lower area than in previous decades, turning the country into the world's biggest wine producer for the first time since statistics began. ${ }^{3}$

The bulk of this increase occurred in Castilla-La Mancha, thereby also illustrating the strengthening of the regional specialization that these processes of transformation entail. The most outstanding case is that of the province of Ciudad Real. Figure 7 shows the surface area expansion that has occurred in recent years, which has been based on the introduction of vineyards in trellis (Ruiz Pulpón, 2013b; Ocon, 2016). Figure 8 shows a detail of this reconversion process involving the coexistence of new and traditional vineyard.

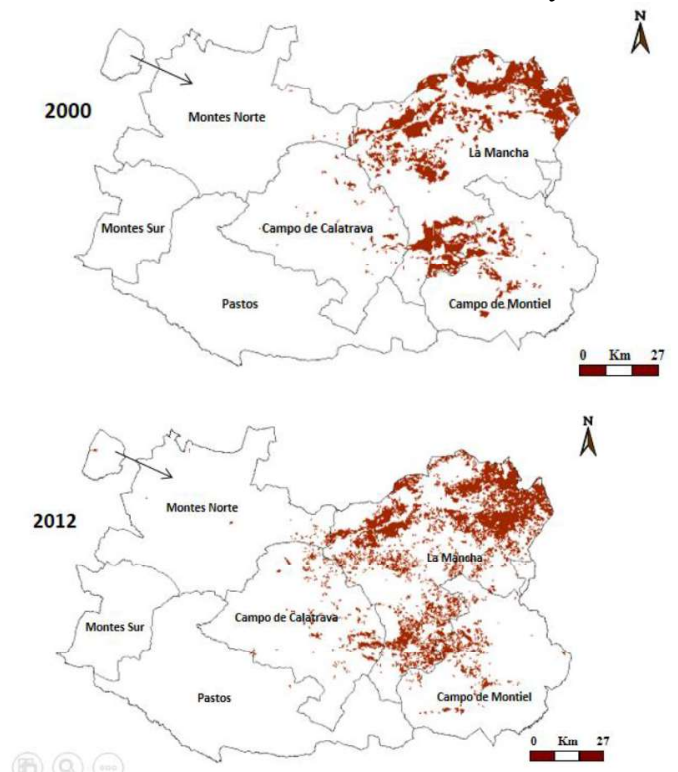

Figure 7. Distribution of vineyards in the province of Ciudad Real, 2000-2012 Source: Corine Land Cover 2000 and 2012.
${ }^{2}$ http://www.mapama.gob.es/es/alimentacion/temas/calidadagroalimentaria/calidad-diferenciada/dop/default.aspx
2015

http://www.elmundo.es/economia/2015/08/20/55d4cd2522601d 7d228b4596.html 


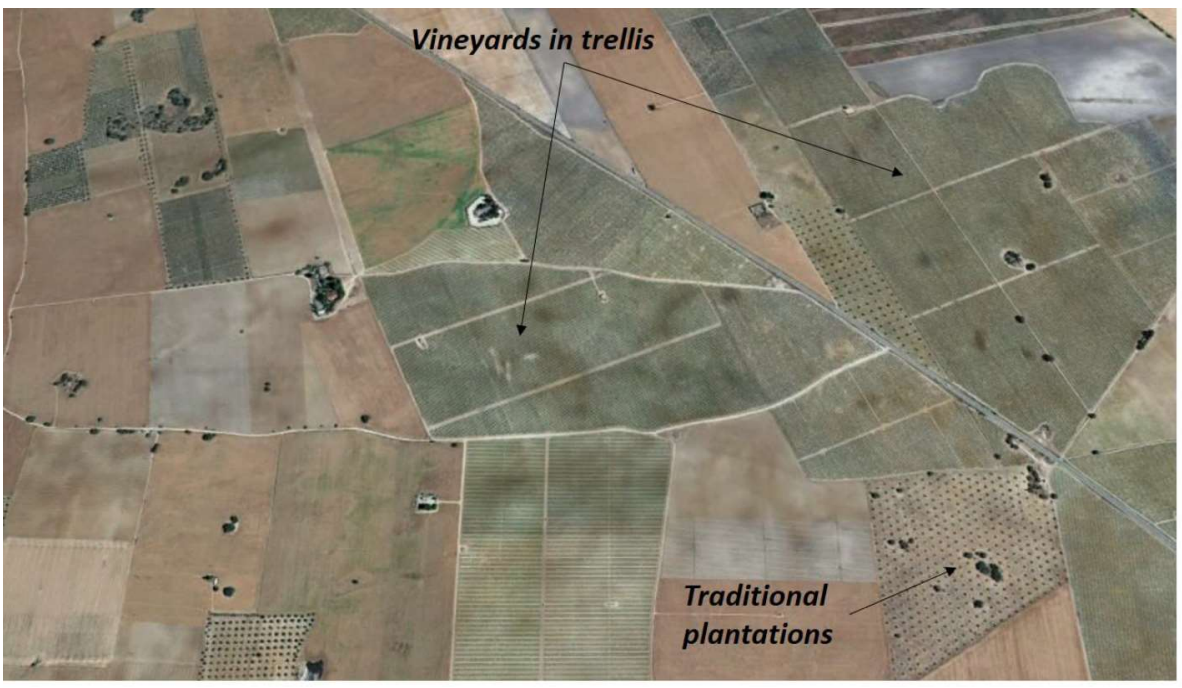

Figure 8. New plantations of vineyards in Molino de Puente Navarro (Ciudad Real), 2016

Source: National Aerial Ortophoto Program (PNOA) - 2016

Of course, the increase in harvests has also been due to irrigation, which already exceeds $40 \%$ of the area used for cultivation (Table 2), a circumstance that is also observed in the province of Jaén with regard to the olive grove.

Table 2

Surface area according to cultivation system (ha) in the provinces of greatest regional specialization, 2014

\begin{tabular}{lllll}
\hline & Rain-fed (a) & Irrigated (b) & Total (c) & \% b/c \\
\hline Olive grove (Jaén) & 311,865 & 273,249 & 585,114 & 46.70 \\
Vineyard (Ciudad Real) & 94,229 & 63,290 & 157,519 & 40.18 \\
Almond tree (Granada) & 71,271 & 3,822 & 75,093 & 5.09 \\
Total & 477,365 & 340,361 & 817,726 & 41.62 \\
\% Compared to Spain & 15.36 & 38.60 & 20.49 & -- \\
\hline & Source: http://www.mapama.gob.es/es/estadistica/temas/publicaciones/anuario-de-estadistica \\
\hline
\end{tabular}

On the other hand, the dynamic expansion of the olive grove worldwide is spectacular, surpassing 11 million ha at the moment. Although its fruit can be consumed whole after an industrial process, oil production is the reason for its recent boom, especially after the recognition of olive oil as a healthy food (Barjol, 2014). In spite of everything, this vegetal fat makes up scarcely $2 \%$ of all the commercialized fats in the world, well below the percentages reached by the fats from palm, soybean or rapeseed.

The province of Jaén is the clearest example of the model of monoculture and extreme productivism of all those we have analysed on this scale in Spain. The total area occupied by this plant exceeds $92 \%$ of the cultivated land and, as also shown in Table 2, almost half has been irrigated (see Figures 9 and 10). 


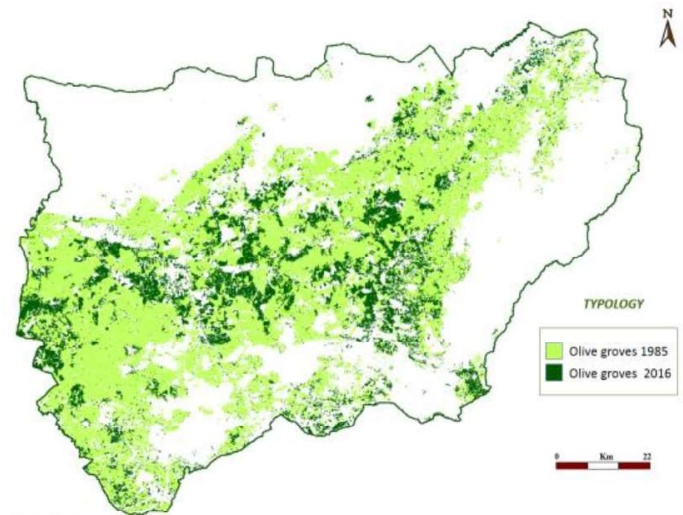

Figure 9. Distribution of olive groves in the province of Jaén, 1985 and 2016

Source: Environmental Information Catalogue of Andalusia 1985 and SIGPAC

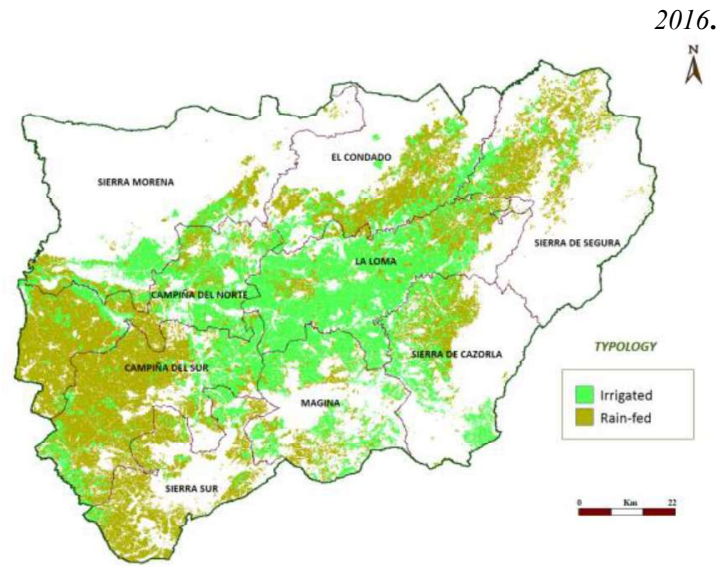

Figure 10. Distribution of rain-fed and irrigated olive groves in 2016

Source: Environmental Information Catalogue of Andalusia

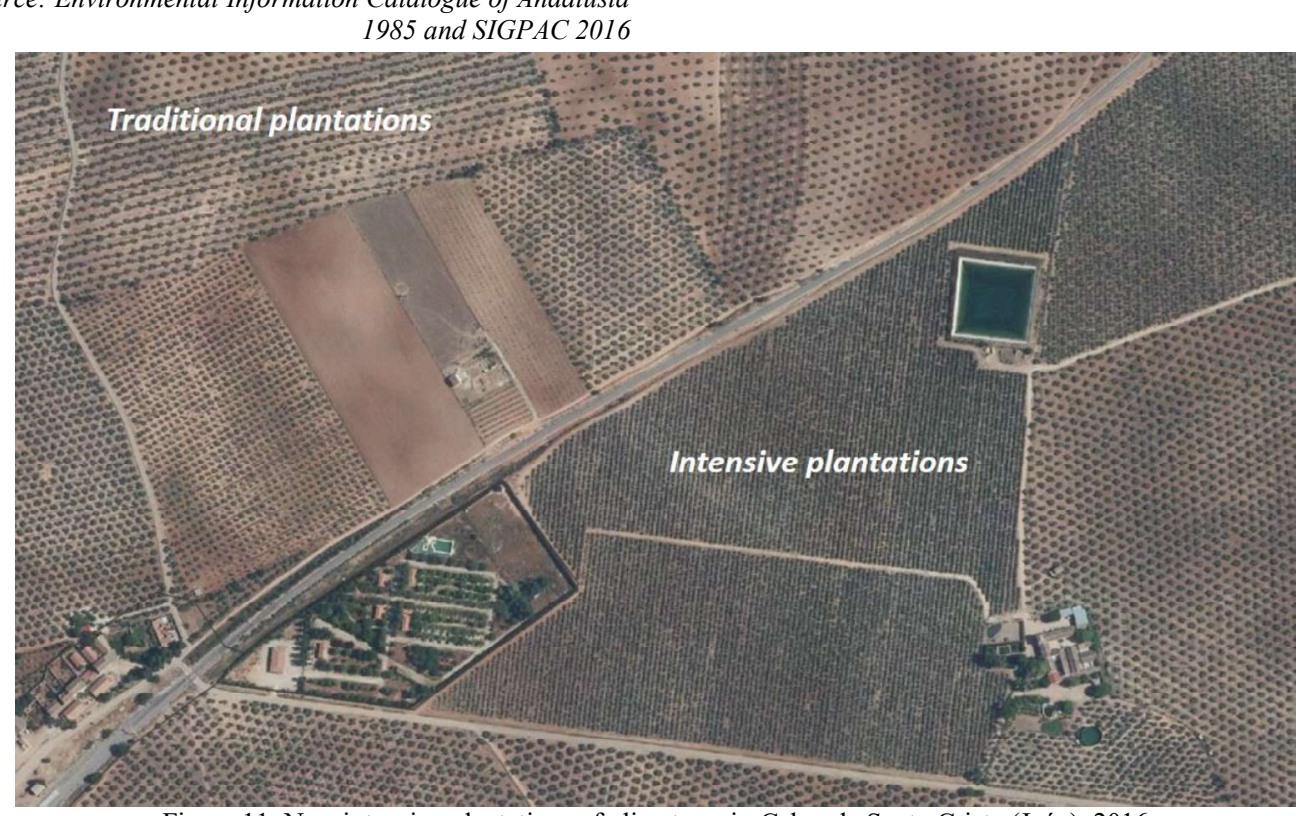

Figure 11. New intensive plantations of olive trees in Cabra de Santo Cristo (Jaén), 2016

Source: National Aerial Ortophoto Program (PNOA) - 2016
The expansion has mainly occurred at the expense of the substitution of rain-fed herbaceous crops, which has meant a profound modification of the pattern of location of the plant, previously reserved for less fertile and more sloped soils and which is now also distributed on the best agricultural land (Paniza Cabrera, García Martínez \& Sánchez Martínez, 2015). Moreover, the scheme of densifying the plantations is repeated in order to obtain an increase in the foliar mass and, therefore, in the obtention of fruit (see Figure 11). For this reason, it is necessary to significantly increase the use of fertilizers and to fundamentally alter the principal cultural labour, because to facilitate mechanization it is now important that the plants have a smaller size and that the formation of trees of great height be impeded.

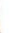


In this case, however, the aspect of varietal renewal has not been so decisive since the dominant olive tree variety (picual) is considered optimum in terms of production and is highly appreciated for the attainment of very stable oils. However, other varieties have been incorporated that respond to organoleptic characteristics of better acceptance among consumers and, at the same time, are easily adapted to the creation of intensive and trellised olive groves (Sánchez Martínez \& Paniza Cabrera, 2015). On the other hand, significant environmental disadvantages derived from productivism have been noted, especially the increase in erosion rates, but also the pressure on the quantity and quality of water resources and the loss of biodiversity (Scheidel \& Krausmann, 2011). The obsession with quantity, finally, has involved giving less attention to the processes of differentiation, although in recent years there has been a changing trend that can still be described as modest (Rodríguez Cohard, Sánchez Martínez \& Gallego Simón, 2016).

\section{DISCUSSION AND CONCLUSIONS}

The trends show an increase in the global demand for almonds, wine and olive oil, which suggests a deepening of the processes of change that we have described in this work, in other words, an increase in the area occupied and an increased role played by the new plantation systems that are irrigated and designed to be completely mechanized. In particular, their status as health products makes them more and more consumed outside the Mediterranean area.

Traditionally the term Mediterranean trilogy was applied to refer to the coexistence of three large agricultural uses: cereal, olive and vineyard. In the case of Spain, a gradual reduction of the former has been observed in favour of the woody crops. And it is not just a recomposition of the surface weight of each one of them, since the latter two are now much more attractive in terms of the market economy, by producing products that are highly appreciated in the so-called global market. In this regard, the trilogy that now imposes itself is the meeting of water, high quality land and financial capital, which are the three decisive factors that allow us to understand why and where the new productivist versions of these booming crops appear. Their development, of course, is closely linked to the incorporation of innovations and real technological milestones both in the production phase and in the transformation of the products. And it seems likely that this trend will continue to strengthen, since the opportunities derived from the use of robotics or drones will only encourage more intense mechanization in order to maintain and increase profitability and optimise the use of natural resources and inputs that this productivist version of agriculture requires. ${ }^{4}$

This surge in woody crops in Spain, therefore, is being based on overcoming some of the traditional characteristics presented by small farming or the generation of abundant wages, which allowed them to be considered as social crops. In all of them, a model is now imposed which implies a profound modification of the agricultural landscape. In this regard, the most prominent feature is the replacement of fragmentation and polyculture with continuity and monoculture. The new landscapes of the olive, the vineyard or the almond tree are more geometric, forming straight lines that are lost on the horizon, only interrupted by the auxiliary roads to the plantations that break this homogeneity. On the other hand, the water irrigation pond is a new omnipresent and characteristic element, as the most palpable symbol and component of the intensification of production.

Analysing the situation at the provincial level, we have been able to verify the existence of very prominent monoculture territories, the rapidity of the changes experienced and, as a final result, the coexistence of traditional production areas, which try to differentiate themselves through the search for certified quality or territorial identity (Angles, Veysseyre \& Cohen, 2013) and even a heritage recognition (Castillo Ruiz \& Martínez Yánez, 2014; Cohen et al., 2012) and the development of a new tourist destination based on landscape quality (Correia \& Brito, 2016; Millán, Hidalgo \& Arjona Fuentes, 2015; Sánchez \& Ortega, 2016; Silva Pérez, Fernández Salinas \& Molinero Hernando, 2016). On the other hand, there are the new zones of intensification that have the objective, at least in the case of almonds and oil, to pursue bulk production at low cost.

Although it has not been the main goal of this work, the environmental effects of the new cultivation designs are not a minor issue. Given that they systematically look for flat lands, the erosion risk is reduced; but it is not the case of water demand, which is the most decisive resource of all that are required for this intensive

${ }^{4}$ https://www.asajajaen.com/sin-categoria/jornadas-tecnicasolivar-ponencias 
agriculture. The overexploitation of aquifers has been pointed out (Sánchez y Gallego, 2016), but also it should be noticed that thanks to the located irrigation systems consumption per unit is lower than the one observed in perennial cultivations. In any case, it does not result on a net save in water consumption, but the increase in the irrigated surface, as paradigmatically happens in the case of irrigation modernization made in the Guadalquivir Watershed (Gómez-Limón y Villanueva, 2017). Lastly, the industrial use of exploitations causes the loss in biodiversity and a bigger demand direct and indirect of fossil fuels, that overrides all the positive effects that could come from the ability to fix $\mathrm{CO}_{2}$ that woody cultivations have. In fact, it is clearly recognized that there is a favorable balance that is reached in the ones managed under ecological criteria (Aguilera, Guzmán et Alonso, 2015).

In some case the european agricultural politics favour the creation of this new agriculture. The most evident is the vineyard that, as it was already said, has taken advantage of funds destined to conversion and restructuring programs to extend across Castilla y León or Castilla-La Mancha. These aid, nonetheless, have not been applied to the other cultivations analyzed. Therefore, the interest in increasing harvesting of olives and almonds is only caused by market stimuli.

\section{ACKNOWLEDGMENTS}

This research is part of a wider research project Entitled "Characterization and perspectives of the olive monoculture in Jaen: its spatial and chronological formation, landscape-agronomic diversity and territorial immediate dynamics", which is funded by the Ministry of Economy, Innovation and Science of the Regional Government of Andalusia (SEJ - 1153, session 2012)

\section{REFERENCES}

[1]. Aguilera, E., Guzmán, G. y Alonso, A. (2015): "Greenhouse gas emissions from conventional and organic cropping systems in Spain. II. Fruit tree orchards". Agronomy for Sustainable Development, 35, 725-737.

[2]. Angles, S., Veysseyre, J. \& Cohen, M. (2013). Appelations d'Origine Protégée oléicoles, terroirs et territoires méditerranéens: une analyse comparative entre les appelations oléicoles en France et Andalousie. SudOuest européen, Revue géographique des Pyrénées et du Sud-Ouest, 36, 123-133.

[3]. Araque Jiménez, E. (2009). La crisis de los espacios de montaña en Andalucía. Estado de la cuestión. Nimbus, $23,24-44$.
[4]. Aznar-Sánchez, J. A., Belmonte-Ureña, L. J. \& VelascoMuñoz, J. F. (2016). Caracterización del cultivo del almendro en secano en Andalucía y propuestas de reconversión. Información Técnica Económica Agraria, $112(3), 317-315$.

[5]. Barjol, J. L. (2014). L'économie mondial d'huile d'olive. OCL, 21(5), D502.

[6]. Binimelis, J. \& Ordinas, A. (2012). Agricultura y postproductivismo en las Islas Baleares. La payesía isleña en los albores del siglo XXI. Scripta Nova: Revista electrónica de geografía y ciencias sociales, 16, 387-424.

[7]. Cano Orellana, A. (2009). Territorio y sostenibilidad. Aproximación a la huella ecológica de Andalucía. Revista de Estudios Territoriales, 84, 115-145.

[8]. Cañizares Ruiz, M. C. \& Ruiz Pulpón, A. R. (2014). El viñedo en Castilla-La Mancha: el reconocimiento de un paisaje cultural. In D. Pavón Gamero (Ed.), XVII Coloquio de Geografia Rural. Revalorizando el espacio rural: leer el pasado para ganar el futuro (pp. 305-316). Girona: Documenta Universitaria.

[9]. Castillo Ruiz, J. \& Martínez Yánez, C. (2014). El patrimonio agrario: definición, caracterización y representatividad en el ámbito de la UNESCO. Boletín de la Asociación de Geógrafos Españoles, 66, 105-124.

[10]. Cohen, M., et al. (2012). L'oliveraie entre espace productif et patrimoine paysager. Une comparaison Andalousie (Espagne) et Alpes du Sud (France). In Y. Luginbühl \& D. Terrason, D. (Eds.), Paysage et développment durable (pp. 143-155). París: Quae éditions.

[11]. Correia R., \& Brito, C. (2016). Wine Tourism and Regional Development. In M. Peris-Ortiz, M. et al. (Eds.): Wine and Tourism. A Strategic Segment for Sustainable Economic Development (pp. 27-39). London: Springer.

[12]. Delgado Cabeza, M. (2002). Andalucía en el siglo XXI. Una economía crecientemente extractiva. Revista de Estudios Regionales, 63, 65-83.

[13]. Escalona Orcao, A. I., Loscertales Palomar, B. \& Climent López, E. (2013). Enfoques, experiencias y propuestas para la mejora de la competitividad territorial de las áreas vitivinícolas: las denominaciones de origen protegidas de la provincia de Zaragoza. Boletín de la Asociación de Geógrafos Españoles, 62, 317-341.

[14]. Esteban Rodríguez, S. \& Climent López, E. (2016). Geografía de los mundos de producción de las denominaciones de origen protegidas de vino en España. In A. R. Ruiz Pulpón, M. A. Serrano de la Cruz \& J. Plaza Tabasco (Eds.): Treinta años de Política Agraria Común en España: Agricultura y multifuncionalidad en el contexto de la nueva ruralidad (pp. 199-212). Ciudad Real: Asociación de Geógrafos Españoles.

[15]. Evans, N. J. (2001): Reflexiones en torno al modelo agropecuario productivista. In F. García Pascual (Ed.): $E l$ mundo rural en la era de la globalización: incertidumbres y potencialidades (pp. 45-64). Madrid: Ministerio de Agricultura, Pesca y Alimentación.

[16]. Gómez-Limón, J. A. \& Villanueva, J. (2017). "La Política Agraria Común y la modernización de regadíos". In Berbel, J. y Gutiérrez-Marín, C. (eds.): Efectos de la modernización de regadios en España (pp. 61-94). Almería: Cajamar Caja Rural.

[17]. Hueso Martín, J. J. \& Cuevas González, J. (2014, Eds.). La fruticultura del siglo XXI en España. Almería: Cajamar Caja Rural.

[18]. Lasanta, T., Inarejos, V. C., Arnáez, J., Pascual Bellido, N. \& Ruiz-Flaño, P. (2016). Evolución del paisaje vitícola en La Rioja (2000-2015): un análisis del papel de 
los programas de reconversión y reestructuración del viñedo. Investigaciones Geográficas, (66), 9-25.

[19]. Lovera, M., Serrano, N. \& Arquero, O. (2016). El cultivo del almendro en Andalucía. Retrieved from

[20]. http://www.interempresas.net/Horticola/Articulos/154034 -El-cultivo-del-almendro-en-Andalucia.html

[21]. Millán, M. G.; Hidalgo, L. A. \& Arjona Fuentes, J. M. (2015). El oleoturismo: una alternativa para preservar los paisajes del olivar y promover el desarrollo rural y regional de Andalucía (España). Revista de Geografia Norte Grande, 60, 195-214.

[22]. Moreno-Pérez, O. M. (2013). Reproducing productivism in Spanish agricultural systems. Research in Rural Sociology and Development, 19: 121-147.

[23]. Ocón, J. (2016). Un nuevo escenario para el viñedo. Cuaderno de Campo, 57, 14-19.

[24]. Organisation for Economic Co-operation and Development, OECD (2006). The new rural paradigm: policies and governance. Retrieved from

[25]. http://ww.oecd.org/gov/regionalpolicy/thenewruralparadigmpoliciesandgovernance.htm

[26]. Rodríguez Cohard, J. C., Sánchez Martínez, J. D. \& Gallego Simón, V. J. (2017). The upgrading strategy of olive oil producers in Southern Spain: origin, development and constraints. Rural Society, DOI: 10.1080/10371656.2017.1285470.

[27]. Ruiz Pulpón, A. R. (2013a). Producción agroalimentaria de calidad y postproducctivismo agrario: El caso de los vinos de pago en Castilla-La Mancha. Anales de Geografia, 33 (2), 137-154

[28]. Ruiz Pulpón, A. R. (2013b). El viñedo en espaldera: nueva realidad en los paisajes vitivinícolas de Castilla-La Mancha. Boletín de la Asociación de Geógrafos Españoles, 63, 249-270.

[29]. Sánchez Martínez, J. D. \& Ortega Ruiz, A. (2016). El monocultivo olivarero jiennense: conformación histórica, valores patrimoniales y proyección cultural-turística. Cuadernos de Turismo, 37, 377-402

[30]. Sánchez Martínez, J. D. \& Paniza Cabrera, A. (2015). The Olive Monoculture in the South of Spain. European Journal of Geograph, 6 (3), pp. 16-29. Retrieved from

[31]. http://www.eurogeographyjournal.eu/articles/EJG020603 CABRERA.pdf

[32]. Sánchez Martínez, J. D. \& Gallego Simón, V. J. (2016): El olivar regado en la Loma de Úbeda como paradigma del productivismo de la PAC. In Ruiz Pulpón, A. R. et al. (Eds.): Treinta años de Política Agraria Común en España. Agricultura y multifuncionalidad en el contexto de la nueva ruralidad (pp. 184-196). Ciudad Real: Asociación de Geógrafos Españoles Ciudad Real.

[33]. Scheidel, A. \& Krausmann, F. (2011). Diet, trade and land use: a socio-ecological analysis of the transformation of the olive oil system. Land Use Policy, 28, 47-56.

[34]. Silva Pérez, R.; Fernández Salinas, V. \& Molinero Hernando, F. (2016). El carácter del paisaje como medio para la identificación de los valores patrimoniales del viñedo español. In A. R. Ruiz Pulpón, et al. (Eds.): Treinta años de Política Agraria Común en España. Agricultura y multifuncionalidad en el contexto de la nueva ruralidad (pp.900-915). Ciudad Real: Asociación de Geógrafos Españoles.

[35]. Van der Ploeg, J. D. \& Roep, D. (2003). Multifunctionality and rural development: the actual situation in Europe. In G. van Huylenbroeck \& G. Durand, Multifunctional Agriculture; A new paradigm for European Agriculture and Rural Development. Ashgate, Hampshire, England. Retrieved from:

[36]. https://www.researchgate.net/publication/258375349 Mu lifunctionality and rural development the actual situa tion in Europe

\title{
Sự tăng trưởng của các vụ mùa cây lấy gỗ Địa Trung Hải ở phía Nam Tây Ban Nha
}

\author{
Garrido Almonacid, A.; Sánchez Martínez, J. D. \\ Đại học Jaén, Tây Ban Nha
}

Ngày nhận bản thảo: 12/12/2017; ngày chấp nhận đăng: 29/01/2018; ngày đăng: 30/3/2018

Tóm tắt-Các khu vực trồng cây lấy gỗ ở Tây Ban Nha từng trải qua một đột mở rộng rất lớn về diện tích. Nhất là, nơi đây còn chứng kiến sự bùng nổ của một cuộc cách mạng xanh - cuộc cách mạng đã tạo nên một mức sản xuất nông sản khổng lồ, có thể nuôi sống cả một vùng nông nghiệp xuất khẩu quan trọng, nổi tiếng với dầu ô liu, rượu và hạnh nhân.

Tiến trình tăng trưởng này đi theo một mẫu số chung: sự chiếm dụng những khu vực đất bằng phẳng, màu mõ nhất và có cấu trúc về mặt chủ quyền thuận lọii cho việc đầu tư; việc sử dụng giống mới; và sự thiết kế mô hình canh tác cây trồng theo hướng dày đặc hơn, trong đó hệ thống thủy lợi là một yếu tố không thể thiếu và là một phần của sự cơ giới hóa đang diễn ra khắp mọi nơi.
Việc quản lý thông tin không gian theo kiểu số hóa đã cho phép chúng tôi lập được bản đồ về sự phát triển của việc sử dụng đất của rù̀ng cây olive, vườn nho và vườn hạnh nhân ở các tỉnh chuyên canh. Tù đó, chúng tôi nhận thấy được góc độ không gian và thời gian chính yếu của các quá trình thay đổi, là những quá trình chưa hoàn thiện song đã tạo nên một biến cải lớn về cảnh quan nồng nghiệp trong đó sự phân nhỏ đất đai cũng như đa canh đang nhường bước cho mối quan tâm về bề mặt và mật độ canh tác, cũng như vấn đề độc canh.

Tù khóa-hạnh nhân, sự thay đổi trong sử dụng đất, vườn ô liu, chủ nghĩa năng suất, vườn nho. 